Poland

\title{
DELIBERATIVE DEMOCRACY IN THE TIME OF CRISIS: PARTICIPATORY INSTRUMENTS AT THE LOCAL LEVEL AND THEIR LIMITATIONS (SOME REMARKS)
}

\begin{abstract}
Purpose of the study: The study provides the reader with the presentation of one of participatory instruments - social consultations at the level of gmina administrative district. The aim of the article is to determine if the participatory instruments at the level of the basic unit of Polish local self-government were limited at the time when some new legal steps were undertaken by the Polish authorities during the coronavirus crisis (April-July 2020).

Research methods: In this particular study theoretical analysis and legal methods (including formal legal method) were applied to approach the raised questions and to formulate conclusions.

Results:In Poland, during the so-called 'lock-down' (April-May 2020), the most popular participatory instruments at the local level - social consultations were able to work. If opinions and projects submitted for consultations were not intended to be held in person, the electronic system was working, therefore the inhabitants of gmina were able to send an electronic version of a prepared form. If the consultations were intended to be held personally, they should have been rescheduled. In the context of the latest events concerning COVID-19 crisis, we may observe the development of the activities of administrative and local bodies which are in connection with the idea of the so-called 'digital state'.

Discussion: The diversity of forms of public participation gives a real opportunity to shape the policies of a state, region, or local government. Citizens themselves
\end{abstract}


implement solutions in the area of administration, social affairs, and economy through their participation in contemporary public dialogue. Public support for the realization of fundamental tasks of local administrative bodies is required in order to make the decisions legitimate and understandable. Polish local self-governmental bodies develop some new tools and forms of communication. Information and communication technologies provide municipalities with the freedom of participation in a decision-making process, and give a real opportunity to faster exchange of information and answers to the local problems.

KeYwORDS: SARS-CoV-2 virus, crisis, social consultations, administrative unit, self-government, participation

\section{INTRODUCTION}

Increasing dissatisfaction with the current form of democracy has stimulated a consistent quest for the way to improve it. In the 21 st century, deliberative (participatory) democracy might be the response to the crisis of representative democracy. The literature concerning the development of deliberative democracy and the forms of participation is as impressive as the phenomenon it describes. The representatives of science try to answer the question how to make political authority trustworthy and legitimate. The publications of John S. Dryzek (1990; 2000; 2009) and James S. Fishkin (1993; 2009) influenced the scientific and social reception of the phenomenon. Jürgen Habermas (1984) and John Rawls (1999) in their works emphasized the value of communication in a community as a sphere in which an autonomous individual has the opportunity to engage in common values. The agreement might be maximized through communication. Deliberative ideas have attracted the attention of state organizations, citizens, and political activists in countries around the world (Elstub et al., 2016, p. 139, Curato et al. 2017, pp. 28-38; Curato et al. 2019). Referendum, elections, social dialogue, and public dialogue are classical instruments of participation of citizens. The diversity of forms of participation gives a real opportunity to shape the policies of a state, region, or local self-governmental entity.

It is significant that perception of political decisions and their legitimization may be strengthened thanks to the appropriate identification 
and application of some participatory instruments. Democratic deliberation may also shift citizens' preferences to particular issues. The role of group identification in the process of deliberation is the subject of worldwide scientific debate (Batalha et al., 2019, pp.1-3). It should be also taken into account that deliberative democracy with its participatory instruments is contemporary the subject of the European scientific discourse, and some of its potential flaws have been identified (Fernández-Martínez et al., 2019, pp. 1-31; Cross, 2019, pp. 1-18; Stokes, 1998, pp. 123-139; Ahlstrom-Vij, 2012, pp. 199-200, Shapiro, 2017, pp. 77). One the one hand, the idea of the deliberative group has been subjected to the critical evaluation (effects such as group polarization, or groupthink). On the other hand, some benefits of group cognition in deliberation have been identified in the worldwide experience (Batalha et al., 2019 p. 1).

The aim of the article is to determine if the participatory instruments at the level of the basic unit of the Polish local self-government were limited at the time when some new legal steps were undertaken by the Polish authorities during the coronavirus crisis (April-July 2020). The main questions the present study strives to answer are: What is the purpose of participatory instruments at the local level? Do social consultations at the local level play an important part in the Polish public life? Were the participatory instruments at the level of gmina administrative unit limited at the time of coronavirus crisis (April-July 2020)? Unfortunately, the modest scope of the article does not allow for an exhaustive treatment of the subject, therefore the work is of a contributory character. The article consists of two parts. At first, mainly social consultations as a form of a public participation are depicted. Then, the so-called 'anti-crisis shield' (the complex package of laws, 2020), which purpose was to protect the society from the adverse economic consequences of the pandemic caused by the SARS-CoV-2 virus (COVID-19), is presented. Special attention is paid to the legal provisions in the context of the activities of local self-government. The article does not provide the assessment of all legal steps undertaken by the Polish authorities during the coronavirus crisis (April-July 2020). 


\section{THE IMPROVEMENT OF PARTICIPATORY INSTRUMENTS IN The Polish Self-governmental AREA}

It is significant that public participation is a highly discussed subject in the public discourse (Maszkowska and Sztop-Rutkowska, 2013; Łabędź, 2015, pp. 93-106; Marchaj, 2017, pp. 18-30). The debate abounds with numerous research and theoretical analysis. It arises from the perception of civil participation as an endogenous factor of the development of a society, which is noticeable in Western Europe (Zychowicz, 2014, p. 19). Public participation means all practices and activities in which citizens may influence public affairs. Public participation absorbs citizens and public organizations in a social life, in public decisions, in resolving some problems and issues. Thanks to public participation the activities are carried openly, and the public is aware of their consequences. Public participation is the ability to take part in activities and decisions of administrative authorities not only in the context of potentially better adjustment of law to the social needs, but also from the perspective of democratic state. It enhances the inclination of the society to the interest in public affairs. Participation can take various forms, which are supposed to consider the different degree of civil engagement in taken decisions.

Political changes in Poland in the last two decades of the 20th century enabled the creation of a new political regime. The undertaken changes promoted the development of deliberative democracy in the 21st century (more in Sokalska, 2019, pp. 55-60). Some questions concerning the instruments and forms of the effective participation and deliberation in the field of local self-government and other areas have appeared. The broad scope of the Polish subject related literature reflects interest in the mentioned field (e.g., Woźniczko, 2019; Zychowicz 2014; Zasady dialogu społecznego, 2002, pp. 3-37; Grosse, 2007, pp. 53-74; Uziębło 2009; Sienkiewicz and Sidor, 2014; Markowski, 2014; Krajewska, 2007, pp. 127-154). The legislator's purpose was to grant local communities autonomy through the decentralization of public authorities, in order to create the conditions that would have facilitated the active resourcefulness of local communities. It was noticed that the perception of political decisions and their legitimization might have been reinforced thanks to the appropriate identification and application of some participatory instruments. 
The Polish legislator has worked on the improvement of participatory instruments in the context of self-governmental activities (Markowski, 2014, pp. 123-139). The consequence of such activities resulted in the amendment of the 11th of January 2018 to the Polish local self-government acts (Ustawa z 11 stycznia 2018 r. o zmianie niektórych ustaw w celu zwiększenia udziału obywateli w procesie wybierania, funkcjonowania i kontrolowania niektórych organów publicznych. Journal of Laws of the Republic of Poland 2018.130), which was the further step towards reinforcing public participation at the local level. The amendment regulates some legal institutions, which can be perceived as the ones that strengthen the development of Polish participatory democracy. They are: the participatory/civil budget, the citizens' legislative initiative, and the participation in the debate on the report on the condition of the local self-governmental unit. The development of public interest and popularity of local participatory budgets found an outlet in the mentioned above amendment, although initially the local self-governmental authorities were not favorably inclined towards the concept (Woźniczko, 2019, p. 5). The first participatory budget was employed in Sopot in 2011 (Kłębowski, 2013, p. 6), while in February 2014, several dozen of Polish towns employed participatory budgets (Kłębowski, 2014, p. 6). The inhabitants of gmina, thanks to the real effects arising from the realization of projects held as a part of participatory budgets in their surroundings, have started to be more interested in taking part in the mentioned mechanism in order to stimulate the changes, which were the most suitable from their perspective.

\section{SOCIAL CONSULTATIONS AND THEIR SIGNIFICANCE IN DELIBERATIVE DEMOCRACY}

The immanent trait of democratic systems is that citizens are provided with the possibility of taking part in the establishment of law and other essential public decisions. The fact of possibility does not determine the effectiveness of such participation, however, in contemporary democratic societies it is perceived as one of civil rights (Woźniczko, 2019, p. 3). In Poland, there are some institutional tools that serve participation of citizens in the decisionmaking process. Most of them are of the deliberative character. They 
provide comments on legal projects and administrative decisions, and they legitimize the undertaken arrangements. Spontaneous or non-institutional forms of participation may also appear in reaching public solutions, e.g., demonstrations, public protests, marches, banners, happenings, and other forms (Zychowicz, 2014, p. 17). In fact, participation, institutionalized or not, can also manifest itself at the different levels of public arena, form central (state) to local level of gmina administrative unit.

The forms of public participation differ in the context of their effectiveness. It seems that public, civic, or social consultations are potentially the most efficient. Being accessible, uncomplicated, and quite often employed by the local authorities, they involve and engage the citizens who are really interested in the subject. They also give the citizens the sense of real cooperation in the process of the development of their local self-governmental entities. Although the definition of the term 'consultations' refers to the opinions of experts or specialists in the chosen domain, the purpose of social consultations is rather the presentation of the opinion regarding the chosen subject. The consultative, not the expert opinion is here the core of undertaken activities. In this context, social consultations rather seek advice and opinion of the citizens who are not experts, and they form and express the view on a particular subject, in which they are directly, sometimes even emotionally, involved. The definitions of social consultations (sometimes called public consultations) are not sharp enough, therefore on the grounds of practice and legal documents, the mechanism of social participation might be characterized as a deliberate (intentional) stage of a decision-making process, in which citizens, groups of people, or citizens' milieu are interested in the subject of the decision (Woźniczko, 2019, p. 7; see also other definitions: Długosz and Wygnański, 2005, p. 23; Makowski, 2013, p. 24; Raport końcowy z badania efektywności mechanizmów konsultacji społecznych, 2011, p. 10).

Public consultations are different than other forms of consultations in terms of the subject, purpose, relations between the subjects, and the role served in society. The characteristic feature of consultations is the inequality and specificity of sides that take part in such activities. This inequality manifests in the different competence, knowledge, and abilities in which the sides of consultations are equipped. The analysis 
of the extensive issues of social consultations indicates that diagnostic, educative, articulatory, participative, legitimizing, monitoring, integrative, preventive, correcting, organizational, and motivating are the most important functions of the discussed consultations (Zychowicz, 2014, pp. 24-27). The dynamic development of social consultations in Poland revealed their manifold functions. The issue of public consultations has been widely discussed in the context of legislative process by the European Union authorities (Mendza-Drozd, 2010. pp. 8-12). Social consultations in Western Europe have often been the trigger of development of local municipalities. In Poland, a lot of projects of Operational Programme Human Capital financed by the European funds in 2007-2013 have been directed towards the propagation and implementation of the idea of good practices of social consultations.

It is significant that the motivation to implement social and public consultations into Polish ground results from the internal and external pressure. The external pressure arises from the EU standards and requirements. At the level of gmina administrative district, social consultations might be of facultative or obligatory character. Facultative consultations may be decided in the important, from the local perspective, matters. Obligatory character of consultations results from the legal acts devoted to the local administrative units (see an example in Marchaj, 2017, pp. 19-20). They may also depend on the object of consultations and relate to the part of society. Local administrative units have been entitled by the Polish legislator to determine the forms, procedure, and rules of consultations (Ustawa z 11 kwietnia 2001 r. o zmianie ustaw o samorządzie gminnym, o samorządzie powiatowym, o samorządzie województwa, o administracji rządowej w województwie oraz o zmianie niektórych ustaw, Journal of Laws of the Republic of Poland 2001.45.497). Making documents concerning consultations available to the public, survey forms, meetings of the local authorities and local representatives with the inhabitants of local administrative districts, research on public opinion using some electronic questionnaires, consultation cards, meetings of inhabitants, receiving opinions and proposals are common forms of consultations at the local level (Długosz and Wygański, 2005, pp. 23-25). 
To turn consultations into an important area of public participation, professionalism and institutional form of the process were needed. Unfortunately, one uniform platform for consultations has not been created, however, the consultations are carried out via many internet sites, e.g., konsultacje.gov.pl. Some of the internet platforms are of informative rather than consultative character. ICT - information and communication technologies shape public opinion and mould the citizen's subjectivity. They have been applied on the local level in order to build the dialogue between local self-government and local society understood in a broad way - local inhabitants, NGO's, and entrepreneurs. Local authorities more frequently transfer the conduct of public dialogue into virtual reality, especially its fundamental forms as information, consultation, and co-decision with the developing significance of communicative functions of the internet, (Kuć-Czajkowska and Wasil, 2014, p. 111). Information and communication technologies give an opportunity to faster answers concerning the local problems and the exchange of important information (Kowalczyk, 2019, pp. 260-262; KućCzajkowska and Wasil, 2014, p. 111).

Two kinds of websites have been applied by Polish local municipalities. The first one (obligatory) is Biuletyn Informacji Publicznej (BIP, Public Information Newsletter). The second one is an official website of the gmina administrative unit. There are diverse instruments to carry out the public dialogue on the mentioned websites, which provide municipalities with the freedom of participation in a decision-making process. The research on the information and communication technologies shows that the fundamental dimension of the public dialogue - information - is realised via BIP. Information enriched with the service functions have been realized by local administrative bodies via ePUAP platform. In order to strengthen bilateral communication and consultations, some internet sites, forum, commenting on-line, dialogue boxes, chat, and questions to administrative bodies of a varied formula have been applied. In the context of consultations and co-decisions, there are applied some more sophisticated and expensive tools, which follow the patterns of the states presenting the higher level of an information society, e.g., Twój Budżet (Your Budget) website in Warsaw 
(Parnes, 2014, p. 122). Via BIP and ePUAP platform local self-governmental bodies may present the project of a local regulation or resolution, they may also carry out social consultations (in order to recognize public opinion concerning the project) and show the detailed information about the effects of the carried consultations. The example here might be the website of Gminny Ośrodek Kultury Goczałkowice-Zdrój (Aktualności, Konsultacje społeczne).

It should be taken into consideration that different information and communication technologies are applied by rural and urban municipalities. Urban administrative units often create a few internet sites devoted to the specific matters, which consequently form a coordinated system of consultation, information, and co-decision. It can be observed that the official websites of local administrative district located in the neighborhood are similar (Parnes, 2014, p. 122). In order to strengthen digital foundations for the national development (common access to a high-speed internet, effective and user friendly public e-services, and a continuously rising level of digital competence of the society) Poland benefits from the European funds according to Operational Programme Digital Poland for 2014-2020.

\section{THE CORONAVIRUS CRISIS, 2020}

In 2020, for several months, the world has been struggling with the pandemic caused by the SARS-CoV-2 virus (COVID-19), called the coronavirus. Undoubtedly, the pandemic can be seen as the time of crisis at many levels, including state economy, political, socio-cultural, or religious planes. In a crisis situation, the question concerning the preservation and respect for human rights may arise. There appear some questions regarding the possibility of making any significant statutory changes, or the limitations and restrictions on civil rights and freedoms in the name of safety reasons, the part of modern mass media and information and communication technologies devices in providing information to the public, or the state activities in order to protect financial security of the country and its citizens. 
During the time of coronavirus crises, Polish authorities undertook some steps in order to counteract the negative effect in Polish economy. It should be taken into account, that the assessment of the mentioned activities, if they were sufficient and adequate or not, is not the core of the article. I rather aim at the determination if up to July 2020, the civil rights of Polish citizens in the context of the development of deliberative democracy at the local level were secured.

The so-called 'anti-crisis shield' is the complex package of laws, which purpose is to protect the society from the adverse economic consequences of the pandemic caused by the SARS-CoV-2 virus (COVID-19). A part of the package of laws came into force on the 1st of April 2020. The package consists of a series of legal acts: the act of the 31st of March 2020 on special solutions related to the prevention, avoidance, and eradication of COVID-19, other infectious diseases and crisis situations caused by them, as well as some other acts (the so-called 'special act'/'specustawa') (Ustawa z 31 marca 2020 r. o szczególnych rozwiązaniach związanych z zapobieganiem, przeciwdziałaniem i zwalczaniem COVID-19, innych chorób zakaźnych oraz wywołanych nimi sytuacji kryzysowych oraz niektórych innych ustaw. Journal of Laws of the Republic of Poland 2020.568); the project of a legal act of the 28th of May 2020 on granting public aid to rescue or restructure entrepreneurs (Ustawa o udzielaniu pomocy publicznej w celu ratowania lub restrukturyzacji przedsiębiorców, the legislative process in progress); the act of the 31st of March 2020 amending the act on the system of development institutions (Ustawa z 31 marca 2020 r. o zmianie ustawy o systemie instytucji rozwoju. Journal of Laws of the Republic of Poland 2020.569); the act of the 19th of June 2020 on interest-rate subsidies for bank loans granted to entrepreneurs affected by the effects of COVID-19, and on simplified proceedings for approval of the arrangement in connection with the occurrence of COVID-19 (Ustawa z 19.06.2020 o dopłatach do oprocentowania kredytów bankowych udzielanych przedsiębiorcom dotkniętym skutkami COVID-19 oraz o uproszczonym postępowaniu o zatwierdzenie układu w związku z występowaniem COVID-19. Journal of Laws of the Republic of Poland 2020.1086). 
In the context of the activities of self-governmental structures, the 'special act' made the management of public funds of the local self-government more flexible. The financial fluidity of local governments during the epidemic was increased by the possibility of earlier transfer of a general subsidy from the state budget to local governments in 2020. The debt repayment capacity of the self-governmental units has increased. By establishing another relationship limiting the amount of debt repayment for 2021 and next years, a self-governmental entity will reduce current expenses in the budget with those which have incurred in 2020 in order to implement tasks related to counteracting COVID-19.

The head of a self-governmental unit, poviat board, or voivodship board have been given the competence to make changes to the plan of income and expenditure of the budget of a local self-governmental unit, including transfers of expenses between budget classification departments. While implementing the local government budget, the head of a commune, the poviat board or the voivodship board were also given theopportunity - without obtaining the opinion of the committee competent for the budget of the body constituting this unit - to change the purpose of the special reserve, and to create a new special-purpose reserve, transferring to it blocked spending amounts (Art. 15zn., Art. 15zo.).

The restrictions on balancing the current part of the budget were temporarily softened. In 2020, current expenses may be higher than current revenues by the expenses incurred in order to implement the tasks related to counteracting COVID-19, in the part, in which they were financed with own funds. In addition, the investment possibilities of local governments were increased by the modification of the relationship limiting the repayment of debt of a local governmental unit for 2020-2025. The deadlines for submitting reports and information prepared by local governmental units were postponed by the regulation of the Minister of Finance. These deadlines were specified in the regulation of the Minister of Finance of 31 March 2020 on the right to specify other deadlines for the fulfillment of obligations in the area of records, and for the preparation, approval, access, and forwarding of reports or information to the appropriate register, unit, or body. In fact, the solutions proposed by 'specustawa' have made the effort to meet the needs of the self-governmental entities. 


\section{Conclusion}

Currently, social consultations are an increasingly frequent part of the Polish public domain activities at the local self-governmental level. Despite the fact that there have been undertaken several positive developments in this sphere, we cannot assume that social consultations (which are not obligatory) are practice that is generally applied. Conviction that it is an efficient form of public participation should be deeper ingrained in our society. Low participation of citizens in social consultations and scarce local initiatives particularly at the local level of rural and small town communities are noticeable. Despite the number of initiatives and expert support via variety of (also financial) projects, the practice of social consultations is not satisfactory. However, the more popular than before is the opinion that social consultations are not only imposed by the law, but also they are genuinely needed for the society.

In Poland, during the so-called 'lock-down' (April-May 2020), at the local level, in my opinion, the most popular participatory instruments were able to work. If opinions and projects submitted for consultations were not intended to be held in person, the electronic system has been working, therefore the inhabitants of gmina were able to send an electronic version of a prepared form. If the consultations were intended to be held personally, they should have been rescheduled. Of course, the issue would have been also considered in the context of the Constitution of the Republic of Poland art. $31 \$ 3$ providing that "any limitations upon the exercise of constitutional freedoms and rights may be imposed only by statute, only when necessary in a democratic state for the protection of its security or public order or to protect the national environment, health or public morals, or the freedoms and rights of other persons". In fact, the 'anti-crisis shield' (statute) did not consider social consultations. Therefore, the change of the term would have been determined by self-governmental decisions. In my opinion, the need to postpone social consultation it was only a technical case. In Poland, in the context of the latest events concerning COVID-19 crisis, we may observe the development of the activities of administrative and local bodies which are in connection with the idea of the so-called 'digital state'. I assume that during the time of the mentioned above crisis, the participatory instruments at the local level were not limited or restricted. 


\section{References}

Ahlstrom-Vij, K. (2012). Why Deliberative Democracy is (Still) Untenable. Public Affairs Quarterly 26(3), pp. 199-220. ISSN 0887-0373.

Batalha, L.M., Niemeyer, S., Dryzek, J.S. and Gastil, J. (2019). Psychological Mechanisms of Deliberative Transformation: The Role of Group Identity. Journal of Public Deliberation 15(1), pp. 1-20. Retrieved (10.06.2020) from https://www.publicdeliberation.net/jpd/vol15/iss1/art2.

Cross, B. (2019). Deliberative systems theory and activism. Critical Review of International and Political Philosophy, pp. 1-18. Retrieved (05.05.2020) from https:// www.tandfonline.com/doi/abs/10.1080/13698230.2019.1584842. https://doi.org/1 0.1080/13698230.2019.1584842.

Curato, N., Dryzek, J.S., Ercan, S.A., Hendriks, C.M. and Niemeyer, S. (2017). Twelve Key Findings in Deliberative Democracy Research. Dædalus. Journal of the American Academy of Arts \& Sciences. The Prospects and Limits of Deliberative Democracy 146(3), pp. 28-38. Retrieved (01.12.2019) from https://www.amacad. org/publication/twelve-key-findings-deliberative-democracy-research. https:// doi.org/10.1162/DAED_a_004444.

Curato, N., Hammond, M. and Min, J.B. (2019). Power in Deliberative Democracy. Norms, Forums, Systems. New York: Palgrave Macmillan. ISBN 9783319955346.

Długosz, D. and Wygański, J. J. (2005). Obywatele współdecydują. Przewodnik po partycypacji społecznej. Warszawa: Stowarzyszenie na rzecz Forum Inicjatyw Pozarządowych. ISBN 9788391498095.

Dryzek, J.S. (1990). Discursive Democracy: Politics, Policy, and Political Science. Cambridge: Cambridge University Press. ISBN 9780521478274.

Dryzek, J.S. (2000). Deliberative Democracy and Beyond: Liberals, Critics, Contestations. New York: Oxford University Press. ISBN 9780199250431.

Dryzek, J.S. (2009). Democratization as Deliberative Capacity Building. Comparative Political Studies 42(11), (pp. 1379-1402). Retrieved (10.05.2020) from https://journals.sagepub.com/doi/10.1177/0010414009332129. https://doi.org/10.1177/0010414009332129.

Sokalska, E. (2019). The Development of Deliberative Democracy and Post-Communist Polish Experience (some remarks). Actual Problems of Law 4 (20), pp. 55-60.

Elstub, S., Ercan, S. and Mendonça, R.F. (2016). The Fourth Generation of Deliberative Democracy. Critical Policy Studies 10(2), pp. 139-151. https;//doi. org/10.1080/19460171.1175956.

Fernández-Martínez, J. L., García-Espín, P. and Jiménez-Sánchez, M. (2019). Participatory Frustration: The Unintended Cultural Effect of Local Democratic Innovations. Administration \& Society, pp. 1-31. https://doi.org/10.1177/0095399719833628. 
Fishkin, J. S. (1993). Democracy and Deliberation: New Directions for Democratic Reform. New Haven: Yale University Press. ISBN 9780300051636.

Gminny Ośrodek Kultury Goczałkowice-Zdrój Aktualności, Konsultacje społeczne. Retrieved (20.05.2020) from http://gok.goczalkowicezdroj.pl/aktualnosc-2-25208-konsultacje_spoleczne_projektu_uchwaly.html).

Grosse, T.G. (2007). Dialog społeczny i obywatelski w Unii Europejskiej. in: R. Towalski (ed.) Dialog społeczny. Najnowsze dyskusje i koncepcje (pp. 53-74). Warszawa: Centrum Partnerstwa Społecznego DIALOG, Fundacja Instytut Spraw Publicznych. ISBN 9788392620303.

Habermas, J. (1984). The Theory of Communicative Action vol. I. Reason and the Rationalization of Society. Boston: Beacon Press. ISBN 9780807015070.

Kłębowski, W. (2013). Budżet partycypacyjny krótka instrukcja obstugi. Warszawa: Instytut Obywatelski. ISBN 9788363874155.

Kłębowski, W. (2014). Budżet partycypacyjny ewaluacja. Warszawa: Instytut Obywatelski. ISBN 9788363874261.

Kowalczyk, M. (2019). Cyfrowe państwo. Uwarunkowania i perspektywy. Warszawa: Wydawnictwo PWN. ISBN 9788301206246.

Krajewska, A. (2007). Konsultacje społeczne w praktyce. Studium dwóch przypadków. in: M. Rymsza (ed.), Organizacje pozarządowe. Dialog obywatelski. Polityka państwa (pp. 127-154). Warszawa: Instytut Spraw publicznych.

Kuć-Czajkowska, K.A. and Wasil, J. (2014). Elektroniczne oblicze władzy lokalnej $w$ Polsce - dialog obywatelski przy użyciu narzędzi ICT. in: M.M. Sienkiewicz and M. Sidor (eds.), Dialog obywatelski: formy, mechanizmy, bariery i perspektywy rozwoju (pp. 111-122). Lublin: Wydawnictwo Fundacji Centrum Rozwoju Lokalnego. ISBN 9788393226122.

Łabędź, K. (2015). Partycypacja obywatelska na poziomie lokalnym - formy i ograniczenia. Przegląd Politologiczny 4, pp. 93-106. ISSN 1426-8876.

Sienkiewicz, M.M. and Sidor, M. (eds.)(2014), Dialog obywatelski: formy, mechanizmy, bariery i perspektywy rozwoju. Lublin: Wydawnictwo Fundacji Centrum Rozwoju Lokalnego. ISBN 9788393226122.

Makowski, G. (2013). Przegląd prawno-instytucjonalnych ram konsultacji społecznych na poziomie samorzadu terytorialnego. in: P. Sobiesiak-Penszko (ed.), Prawo a partycypacja publiczna. Bilans monitoringu (pp. 24-45). Warszawa: Instytut Spraw Publicznych. ISBN 9788376891101.

Marchaj, R. (2017). Konsultacje społeczne w sprawie utworzenia związu metropolitalnego w województwie śląskim. Metropolitan 1(7), pp. 18-30. ISSN 2353-7558. 
Markowski, R. (2014). Demokracja i demokratyczne innowacje. $Z$ teoria w praktykę. Warszawa: Instytut Obywatelski. Retrieved (10.05.2020) from http://www.instytutobywatelski.pl.

Maszkowska, A. and Sztop-Rutkowska, K. (2013). Partycypacja obywatelska - decyzje blizsze ludziom. Białystok: Fundacja Laboratorium Badań i Działań Społecznych.

Mendza-Drozd, M. (2010). Zagadnienie konsultacji społecznych w Unii Europejskiej. Analiza wybranych instytucji i dokumentów, opracowanie w ramach zleconego przez Ministerstwo Pracy i Polityki Społecznej „Badania efektywności mechanizmów konsultacji społecznych" realizowanego w ramach Programu operacyjnego Kapitał Ludzki 2007-2013 współfinansowanego przez Unię Europejską w ramach Europejskiego Funduszu Społecznego, Warszawa sierpień 2010. Retrieved (05.05.2020) from http//www. partycypacjaobywatelska.pl/uploads/2b_konsultacje_ue_raport.pdf.

Parnes, J. (2014). Rola ICT w rozwoju lokalnego dialogu obywatelskiego. in M.W. Sienkiewicz and M. Sidor (eds.), Dialog obywatelski: formy, mechanizmy, bariery i perspektywy rozwoju (pp. 123-130). Lublin: Wydawnictwo Fundacji Centrum Rozwoju Lokalnego. ISBN 9788393226122.

Rawls, J. (1999). A Theory of Justice. Revised Edition. Oxford-New York: Oxford University Press. ISBN 0674017722.

Shapiro, I. (2017). Collusion in Restraint of Democracy: Against Political Deliberation. Dædalus. Journal of the American Academy of Arts \& Sciences. The Prospects and Limits of Deliberative Democracy 146(3), pp. 77-84. Retrieved (06.05.2020) from https://www.mitpressjournals.org/doi/full/10.1162/DAED_a_00448. https://doi. org/10.1162/DAED_a_00448.

Stokes, S.C. (1998). Pathologies of Deliberation. in: J. Elster (ed.), Deliberative Democracy (pp. 123-139). New York: Cambridge University Press. Retrieved (07.05.2020) from https://www.cambridge.org/core/books/deliberative-democracy/pathologies-of-deliberation/01661C8DE915C3C8C362FF579A413A2E. https://doi.org/10.1017/CBO9781139175005.007.

Uziębło, P. (2009). Demokracja partycypacyjna. Gdańsk 2009: Centrum Badań Społecznych. ISBN 9788392969303.

Woźniczko, J. (2019). Konsultacje społeczne jako narzędzie partycypacji publicznej. Opracowania tematyczne, OT-666, Kancelaria Senatu, pp. 3-24. Retrieved (10.06.2020) from http:// www.senat.gov.pl/gfx/senat/pl/senatopracowania/171/ plik/ot_666/pdf.

Zychowicz, Z. (2014). Konsultacje społeczne w samorzadzie. Szczecin: Instytut Rozwoju Regionalnego. ISBN 9788388312205. 


\section{Legal acts and public documents}

Operational Programme Digital Poland for 2014-2020. Retrieved (04.04.2020) from http://www.fundusze europejskie.gov.pl/media/10410/POPC_eng_1632015.pdf.

Operational Programme Human Capital. Retrieved (05.05.2020) from https://www. funduszeeuropejskie.gov.pl/efs/Dokumenty/Lists/Dokumenty\%20programowe/ Attachments/87/Program_Operacyjny_Kapital_Ludzki_05122011.pdf.

Raport końcowy z badania efektywności mechanizmów konsultacji społecznych, znak sprawy: 43/DPP/PN/2009 (2011) (Warszawa: Program Operacyjny Kapitał Ludzki 2007-2013). Retrieved (20.05.2020) from http://www. pożytek.gov.pl/files/Biblioteka/raport_efekt_konsult.pdf.

The Constitution of the Republic of Poland. Journal of Laws of the Republic of Poland 1997.78.483.

Ustawa z 31 marca 2020 r. o szczególnych rozwiązaniach związanych z zapobieganiem, przeciwdziałaniem i zwalczaniem COVID-19, innych chorób zakaźnych oraz wywołanych nimi sytuacji kryzysowych oraz niektórych innych ustaw. Journal of Laws of the Republic of Poland 2020.568).

Ustawa z 31 marca 2020 r. o zmianie ustawy o systemie instytucji rozwoju. Journal of Laws of the Republic of Poland 2020.569.

Ustawa z 11 kwietnia 2001 r. o zmianie ustaw o samorządzie gminnym, o samorządzie powiatowym, o samorządzie województwa, o administracji rządowej w województwie oraz o zmianie niektórych ustaw. Journal of Laws of the Republic of Poland 2001.45.497.

Ustawa z 11 stycznia 2018 r. o zmianie niektórych ustaw w celu zwiększenia udziału obywateli w procesie wybierania, funkcjonowania i kontrolowania niektórych organów publicznych. Journal of Laws of the Republic of Poland 2018.130.

Ustawa z 19.06.2020 r. o dopłatach do oprocentowania kredytów bankowych udzielanych przedsiębiorcom dotkniętym skutkami COVID-19 oraz o uproszczonym postępowaniu o zatwierdzenie układu w związku z występowaniem COVID-19. Journal of Laws of the Republic of Poland 2020.1086.

Zasady dialogu społecznego. Dokument programowy Rządu przyjęty przez Rade Ministrów w dniu 22 października 2002 r. Załącznik nr 1. Dialog społeczny - istota, pojęcia, metody. Warszawa: Rada Ministrów, pp. 3-37. 